\title{
STUDI FENOMENOLOGIS TERHADAP PERAN ETIKA DALAM PENDIDIKAN PERPAJAKAN
}

\author{
Tri Rahayu Widyaningrum \\ Dosen STIE Asia Malang
}

\begin{abstract}
Ethics, has a very important role in all aspects including the aspect of taxation Education. The existence of ethics is absolutely necessary within the framework of a healthy mindset and full balance so that the education process running for this not only focus on improving the capabilities, expertise and intellectual, but also pay attention to morality that comes to fruition ethics in the construction of education completely. This study aims to assess the understanding of the students in terms of knowledge about the role of ethics in education tax.The extent to which their understanding in terms of ethics and critical payloads contained in it. Phenomenology is used as an analytical tool understanding of the role of ethics in education tax. These findings indicate that students understanding the role of ethics that is so important in the educational process of taxation and will be used as stock ethics profession as a career offender taxes. significantly still needed effort for understanding the role of ethics in education taxation can achieve balance by integrating a variety of clever angles and interests as a whole.
\end{abstract}

Keywords: Ethics, education, tax

\section{ABSTRAKSI}

Etika, memiliki peran yang sangat penting dalam semua aspek termasuk di dalamnya dalam aspek Pendidikan perpajakan. Keberadaan etika mutlak diperlukan dalam kerangka pola pikir yang sehat dan penuh keseimbangan agar proses pendidikan yang berjalan tidak hanya bertumpu pada peningkatan kemampuan, kepiawaian dan kecerdasan intelektual, namun juga memperhatikan moralitas yang muncul berbuah etika dalam konstruksi pendidikan seutuhnya. Penelitian ini bertujuan untuk mengkaji pemahaman anak didik dalam hal pengetahuan mengenai peran etika dalam pendidikan perpajakan. Sejauh mana pemahaman mereka dalam hal etika serta muatan penting yang termaktub di dalamnya. Fenomenologi digunakan sebagai alat analisis pemahaman peran etika dalam pend idikan perpajakan. Temuan ini mengindikasi bahwa anak didik mamahami peran etika yang begitu penting dalam proses pendidikan perpajakan dan akan digunakan sebagai bekal berkarir menjalani profesi sebagai pelaku pajak. Secara signifikan masih dibutuhkan upaya agar pemahaman peran etika dalam pendidikan perpajakan dapat mencapai keseimbangan dengan mengintegrasikan berbagai sudut pandai dan kepentingan sebagai sebuah keutuhan.

Kata kunci: etika, pajak, pendidikan

\section{PENDAHULUAN}

Permasalahan pajak di berbagai level kepentingan begitu banyak membelenggu negara ini. Permasalahan ini ditengarai tidak terlepas dari masalah moralitas yang belakangan menjadi kian menganga. Hampir di berbagai media, baik cetak maupun elektronik dihiasi oleh praktek-praktek perpajakan yang minus moralitas dan menciderai makna pajak yang sesungguhnya. Terjadinya praktek manipulasi dan rekayasa pajak yang dilakukan banyak pihak. Hal ini secara signifikan berpengaruh pada penerimaan pajak yang seharusnya dan secara otomatis kondisi ini menghambat distribusi kemakmuran yang seharusnya bisa dirasakan oleh seluruh warga di negara ini (Mulia:2012).

Sejumlah permasalahan perpajakan yang semakin masif menyentil semua pihak untuk terus berfikir ulang mengenai ketimpangan ini dan mencari jalan keluar dari permasalahan yang ada. Permasalahan yang entah bisa atau tidak terselesaikan dengan sempurna demi kemakmuran seluruh penduduk sesuai dengan anamat Undang Undang dasar 1945 bahwa seluruh alam dan kekayaan di negara ini adalah milik negara dan digunakan sebesar-besarnya untuk kemakmuran rakyat.

Dari berbagai kondisi tersebut, salah satu hal yang bisa dijadikan sebagai alat pengayom adalah dengan cara menajamkan lagi peran etika dalam perpajakan dalam hal ini adalah pendidikan perpajakan. Dalam arti kata pendidikan perpajakan yang diberikan tidak hanya sekedar teori dan praktek namun juga perlu mengugah kembali kesadaran mengenai etika yang sudah pasti bersinggungan dan melekat pada semua wajib pajak di negara ini. Penajaman peran etika dalam pendidikan perpajakan diyakini mampu mencegah kondisi yang kurang terpuji di kemudian hari dan membekali anak didk 
dengan moralitas. Bagaimana mencegah dan membentengi diri dari perbuatan negatif yang dapat menciderai kepercayaan masyarakat dan negara serta secara berkesinambungan dapat merugikan masyarakat khususnya dan negara pada umumnya melalui terhambatnya proses pembangunan di negara ini.

\section{METODE}

Penelitian ini merupakan jenis penelitian kualitatif dengan menggunakan paradigma Interpretif. Pendekatan yang digunakan dalam penelitian ini adalah fenomenologi. Studi fenomenologis bertujuan untuk memahami respon terhadap keberadaan masyarakat/manusia, serta pengalaman yang dipahami dalam interaksi tersebut (Saladien, 2006). Fenomenologi merupakan pengalaman subjektif atau suatu studi tentang kesadaran dari perspektif pokok dari seseorang (Moleong 2006:14). Di dalam ulasannya penelitian ini menjelaskan fenomena sosial yang ada dengan mengembangkan konsep dan menghimpun fakta, tetapi tidak melakukan pengujian hipotesis.

Germanic Philosofical Interests menurunkan paradigma interpretif yang menekankan pada peranan bahasa, interpretasi dan pemahaman. Bagi paradigma ini, paradigma tidak hanya digunakan untuk menjelaskan (to explain) dan memprediksi (to predict), tapi juga untuk memahami (to understand). Terdapat 3 komponen fundamental di dalam desain riset fenomenologis diantaranya yaitu, peneliti perlu menentukan batasan apa dan siapa yang akan diinvestigasi, pengumpulan data serta analis is data fenomenologis (Sanders:1982). Dalam penelitian ini konsep-konsep praktis dianalisis dengan cara mengkomparasikan pemahaman atau temuan atas proses pendidikan perpajakan yang bersifat empirik dengan keberadaan etika profesi dalam pendidikan tersebut serta konsepkonsep lainnya yang terkait.

\section{Situs, Informan dan Pengumpulan data}

Situs yang dipilih dalam penelitian ini adalah lembaga pendidikan profesi satu tahun Wearnes Education Center yang ada di kota Malang, Provinsi Jawa timur. Sedangkan informan yang terpilih dalam penelitian ini adalah Nanik, mahasiswa jurusan komputer aplikasi bisnis dan ekspor impor (KABAPEKSIM) dan Harijadi mahasiswa jurusan Komputer aplikasi ekonomi bisnis dan perpajakan (KABIPA). Alasan penulis memilih kedua informan tersebut karena keduanya memiliki pikiran yang unik dan berbeda-beda.

Obyek analisis pada penelitian ini adalah peran etika profesi dalam pendidikan perpajakan yang memiliki keterkaitan erat dalam keberhasilan pendidikan. Di dalam proses pendidikan terdapat interaksi antara individu (anak didik) dengan materi perpajakan yang disampaikan selama proses pendidikan perpajakan. Selain itu, Pemilihan informan dilakukan tidak hanya melalui intuisi pribadi semata namun juga melibatkan pihak luar (triangulasi informasi) yang melibatkan mahasiswa dan pengajar perpajakan. Teknik pengumpulan data pada penelitian ini dilakukan berdasarkan Metode Stone (1978) dengan melakukan kajian teoritis, studi lapangan (Wawancara dan Observasi).

Dalam penelitian ini penulis memilih teknik analisis data sesuai dengan pendekatan studi fenomenologi seperti yang dijabarkan Sanders (1982). Terdapat 4 tahap dalam analisa fenomenologi diantaranya, mendeskripsikan fenomena dari hasil wawancara yang telah direkam. Tahapan kedua yaitu mengidentifikasi tema yang muncul dari deskripsi pada tahap pertama. Tahap berikutnya yaitu tahapan ketiga yaitu pengembangan noema dan noesis. Tahap terakhir dalam penelitian ini adalah mengabstraksikan esensi dari korelasi noema dan noesis, atau disebut juga eidetic reduction.

HASIL

Menurut Nanik, etika dalam pendidikan perpajakan sudah seharusnya dipahami dengn suara hati.

“ ya kalau menurut saya sih, etika itu emang penting, supaya ada yang mengatur. Soalnya orang-orang itu suka sak karepe dewe atau ngawur. Jadi kalau dalam pendidikan perpajakan diajari etika, itu kan maksudnya baik, agar tidak terjadi penyelewengan pajak. Nggak dikorupsi dan wedhi duso mlebu neroko".

Berdasarkan pendapat awal (noema), Nanik menyadari bahwa etika dalam kan pendidikan perpajakan memiliki peran yang sangat penting. Etika ibarat alat monitoring yang berfungsi untuk mengukur pantas tidaknya suatu tindakan dilakukan. Menurut Nanik, pendidikan perpajakan hendaknya tidak berjalan begitu-begitu saya. Hanya berkutat pada pembahasan di modul yang tersimpul melalui slide dan tertampil dalam LCD. Belum lagi selain modul masih ada praktikum yang cukup tebal lebih dari 50 halaman baik soal maupun pembahasannya. Dalam proses mengerjakan praktikum tersebut, Nanik tidak begitu mengalami kesulitan karena background pendidikan sebelumnya adalah pendidikan akuntansi. Dalam hal pemahaman materi perpajakan Nanik juga tidak begitu kesulitan, 
ditambah lagi dalam mengikuti perkuliahan nanik dibimbing oleh seorang pengajar yang memiliki paradigma interpretif yang menggunakan olah rasa dan olah batin dalam pengajarannya. ditambah lagi beliau memberikan materi tidak hanya sekedar bagaimana cara menghitung pajak namun juga memberi muatan moral dalam bentuk etika profesi yang seharusnya dimiliki oleh seorang pelaku pajak. Hal ini tidak heran bila kemudian bentukan etika yang dibangun oleh pengajar mudah terserap oleh anak didik dan mereka sepakat dengan pentingnya etika dalam pendidikan perpajakan.

Dari penjabaran yang disampaikan nanik tadi dapat diketahui alasan (intentional analysis) mengapa noesis Nanik menyatakan bahwa peran etika dalam materi perpajakan sangat penting. Etika profesi yang dimaksudkan tidak hanya sekedar "tepat" dalam perhitungan dan pembayaran pajak tapi juga dimilikinya kesadaran nyata akan fitrahnya sebagai umat manusia. Bahwa pajak adalah iuran dari rakyat untuk rakyat sesuai Undang-Undang nomer 16 tahun 2009, yang memiliki definisi "kontribusi wajib kepada negara yang terutang oleh orang pribadi atau badan yang bersifat memaksa berdasarkan Undang-Undang, dengan tidak mendapatkan imbalan secara langsung dan digunakan untuk keperluan negara bagi sebesarbesarnya kemakmuran rakyat. Di sisi lain menurut fungsinya, pajak memiliki fungsi yaitu: fungsi anggaran (budgetair), hal ini dimaksudkan pajak sebagai sumber dana bagi pemerintah, digunakan untuk membiayai pengeluaran negara, sedangkan untuk fungsi mengatur (regulerend) pajak dimaksudkan sebagai alat pengatur atau melaksanakan pemerintahan dalam bidang sosial ekonomi (Mardiasmo 2011 : 1). Dari kedua fungsi tersebut dapat dipahami bahwa pajak memiliki peran penting bagi negara. Pajak seolah menjadi tiang kokoh pendiri negeri ini. Untuk itu, maka pendidikan perpajakan harus terlaksana dengan baik, mampu menghasilkan masyarakat yang melek pajak dan sekaligus berkualitas dalam sektor perpajakan.

Begitu besarnya manfaat yang diperoleh dari "pajak", membuat Nanik begitu yakin jika pendidikan yang berkaitan dengan perpajakan harus dibarengi dengan penerapan etika yang benar dari semua wajib pajak di negeri ini. Akan menjadi salah apabila peran "etika" dalam pendidikan perpajakan tidak dimunculkan, mengingat hal ini bisa memicu terjadinya minus moralitas praktek perpajakan di tanah air, tak heran bila kemudian Nanik menegaskan pendidikan pajak perlu didasari dengan etika dan berpedoman pada Ethical base tax education. Hal ini semata-mata untuk mengurangi munculnya perilaku kurang terpuji saat pembayaran pajak yang tentu saja sangat merugikan banyak pihak khususnya pemasukan negara dan dapat menciderai kepercayaan masyarakat yang selama ini rutin membayar pajak dan berperan serta pada pembangunan.

Sekarang bagaimana kita lihat noema Harijadi, selaku informan kedua. Dalam proses pendidikannya, menyerap materi perpajan Harijadi juga tidak begitu mengalami kesulitan. Bahkan dia menyatakan:

"ya kalau ndak ada etika dalam pendidikan pajak, lalu apa bedanya pajak dengan ilmu hitung, cuman menghitung doang tidak lebih dari itu, terus ngapain dong, orang-orang bisa seenaknya sendiri menghitung iki bener opo iki salah, iki oleh opo ora oleh."

Dari noema tersebut terlihat bila Harijadi masih memiliki rasa kegamangan dan kekhawatiran akan materi pajak yang selama ini disampaikan. Noesis selanjutnya adalah penjelasan bahwa sebenarnya etika itu penting. Peran yang perlu dimiliki etika perlu digarisbawahi sebagai sesuai yang penting dan tidak boleh dibiarkan begitu saja, hingga kemudian eidetic reduction yang muncul adalah pola penggambaran terpadu antara materi perpajakan, bahan ajar, kurikulum dan penambahan pemaknaan sosial dalam proses pembelajaran dengan menghadirkan peran etika secara general menjadi satu kompilasi utuh dalam rangka mendidik generasi penerus negara ini.

\section{PEMBAHASAN}

Kedua informan tersebut dalam memahami peran etika dalam pendidikan perpajakan diperoleh dari berbagai proses, dan proses tersebut merupakan rangkaian dari pengalaman hidupnya. Berdasarkan hasil dari studi fenomenologis terhadap kedua informan, pemahaman mereka mengenai peran etika dalam pendidikan perpajakan diperoleh dari karakter mahasiswa, pengalaman dan karakter dosen.

Karakter sebagai mahasiswa mempengaruhi pola pikir mereka, termasuk dalam memahami peran etika profesi. Kedua informan dalam penelitian ini memiliki karakter yang berbeda sehingga pemahaman terhadap peran etika dalam pendidikan perpajakan berbeda pula. Nanik adalah orang yang berkarakter sabar, religius dan tegas sehingga membuatnya lebih mudah memahami peran etika dalam proses pendidikan perpajakan. Harijadi adalah orang yang kritis, berjiwa 
sosial, religius, penyabar dan lebih mudah memahami peran etika dalam pendidikan perpajakan sehingga Harijadi dapat memahami peran etika dalam pendidikan perpajakan dengan baik. Hal ini terbukti dengan nilai praktikum perpajakan yang dimiliki Harijadi 85 sedangkan sedangkan Nanik 80, di sisi lain dalam proses pembelajaran juga terlihat peran etika dalam pendidikan perpajakan secara signifikan seperti munculnya nilai-nilai kejujuran dari kedua orang tersebut. Mereka selalu sportif dalam mengerjakan tugas dan tidak malu bertanya, hal ini yang memperlihatkan munculnya peran etika selama proses pendidikan berlangsung.

Hampir seluruh pemahaman mengenai makna etika dalam pendidikan perpajakan diperoleh dari pengalaman mereka selama proses belajar mengajar. Semua informan merupakan anak didik yang sudah menempuh pendidikan perpajakan selama 17 kali pertemuan atau sekitar satu semester. Pada saat itu hampir seluruh mata kuliah perpajakan telah mereka tempuh sehingga menurut penulis mereka telah memahami perpajakan dengan baik. Selain dari pengalaman selama proses belajar mengajar ternyata mereka juga mendapatkan pemahaman mengenai peran etika dalam dari banyak hal seperti dari buku/modul, dari koran/majlah, dari internet dan berbagai sumber lainnya. Sedangkan untuk pemahaman lebih luas bisa diperoleh dari hasil interaksi dengan kehidupan masyarakat secara langsung di lingkungan sekitarnya (Triyuwono:2012).

Pendidik perpajakan dalam hal ini pengajar memiliki peran yang sangat besar dalam memunculkan pemahaman etika perpajakan, karena pendidik adalah salah satu pemeran penting dalam proses belajar mengajar selama proses pendidikan berlangsung. Terdapat salah satu elemen penting dalam perubahan pendidikan akuntansi supaya terlepas dari sekularisasi yaitu peran dari pendidik perpajakan. Sebelum proses belajar mengajar dimulai pendidik harus menyadari terlebih dahulu bahwa pendidikan perpajakan (etika) membutuhkan penyatuan dari berbagai kecerdasan. Para pendidik juga perlu menyadari bahwa setiap diri mereka perlu memiliki semacam kompetensi agar dapat memberikan perubahan terhadap pendidikan perpajakan. Metode pembelajaran dan paradigma pendidik juga sangat berperan penting dalam membentuk pemahaman. Untuk itu maka pendidik perlu memiliki keadaran dalam memberikan ilmu dengan menggunakan kolaborasi antara metode yang digunakan dengan paradigma yang digunakan agar tercapai pemaknaan lebih dalam mengenai peran etika dalam pendidikan perpajakan.

\section{SIMPULAN}

Tujuan utama pendidikan adalah untuk adab dan peradaban (Al-Attas:1981). Dalam studi fenomenologis pemahaman mengenai pendidikan perpajakan jika dilihat dari kulit luarnya masih didominasi oleh kecerdasan intelektual. Namun melalui epoche, dapat diketahui bahwa informan dapat memahami peran etika pajak dari sudut pandang kecerdasan intelektual. Di sisi lain bentuk pemahaman etika pajak seperti menurut Nanik dan Harijadi tidak hanya dipahami secara teoritis namun juga perlu dipahami berdasarkan hati agar tercipta keseimbangan dalam pendidikan perpajakan. Bagi Harijadi pembelajaran etika dalam perpajaran perlu terus ditingkatkan kualitasnya untuk mencegah dan mengurangi hal-hal negatif yang banyak sekali bersliweran di sekitar kita, seperti pengemplangan pajak, korupsi, dan aktivitas lain yang merugikan negara. Penguatan peran etika dalam pedidikan perpajakan tentu saja akan disambut positif oleh semua pihak khususnya wajib pajak.

\section{DAFTAR RUJUKAN}

1. Ardi Mulia, Etika perpajakan berbasis etika Pancasila, Jurnal Madani Edisi I/ Mei 2012

2. Al-Attas, S.M.A.N. 1981. Islam dan Sekularisme. Terjemahan. Penerbit Pustaka. Bandung

3. Bertens, K. 2000. Pengantar Etika Bisnis. Penerbit Kanisius. Yogyakarta.

4. Dewantara, K.H. 1967. Karya Ki Hadjar Dewantara: Kebudayaan, jogyakarta: Madjelis Luhur Persatuan Taman Siswa

5. Ekasari, K. 2012. Internalisasi Nilai-nilai Pancasila dalam pendidikan Akuntansi. Prosiding Konferensi Nasional Pendidikan Akuntansi Indonesia, Jurusan Akuntansi FEB Universitas Brawijaya \& IAI KAPd.

6. Kamayanti, A. 2016, Metodologi Penelitian Kualitatif Akuntansi, Yayasan rumah paneleh, Jakarta, cetakan 2.

7. Hadiwinata, Bob Sugeng. 2002. Polotic Bisnis International Kanisius.

8. Moleong, L.J. 2006. Metode Penelitian Kualitatif. Bandung: ROSDA

9. Mudjianto. B. Dan N. Kenda. 2008. Metode Fenomenologi sebagai salah satu Metodologi Penelitian Kualitatif dalam Komunikologi. Jurnal ilmiah. (http://jurnal.pdii.lipi.go.id/admin/jurnal/111 05585.pdf)

10. Mulawaman, A.D.2010. "Integrasi Paradigma Akuntansi: Refleksi atas 
pendekatan Sosiologi dalam ilmu Akuntansi:. Jurnal Akuntansi Multiparadigma. Volume 1, Nomer 1, hal 161-162.

11. Sanders, P.1982. "Phenomenology:A New Way of Viewing Organizational Research". Academy of Managemen Review. Vol 7, No.3, hal 353-360.

12. Triyuwono, I. 2009. Perspektif Metodologi, dan Teori Akuntansi Syariah. Jakarta: Rajawali Press. 